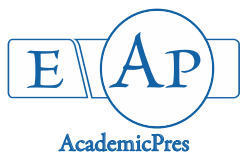

Abubakar A et al. (2020)

Notulae Scientia Biologicae 12(4):807-817

DOI: $10.15835 / 12410818$

Research Article

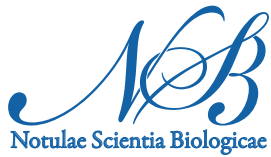

\title{
Evaluation of pearl millet (Pennisetum glaucum L. (R. Br.)) landraces for resistance to stem borer (Coniesta ignefusalis Hampson.) infestation
}

\author{
Abdulhakeem ABUBAKAR ${ }^{1 *}$, Olamide A. FALUSI ${ }^{1}$, Israel K. \\ OLAYEMI $^{2}$, Matthew O. ADEBOLA ${ }^{1}$, Yusuf O.A. DAUDU ${ }^{1}$, \\ Mohammed C. DANGANA ${ }^{1}$ \\ ${ }^{1}$ Federal University of Technology, School of Life Sciences, Department of Plant Biology, PMB 64, Minna, Nigeria; \\ abuakim2007@gmail.com ("correspondingauthor); falusiolamide@gmail.com; ademolamo@gmail.com; \\ dauduoladipupoyusuf@yahoo.com; dangana@futminna.edu.ng \\ ${ }^{2}$ Federal University of Technology, School of Life Sciences, Department of Animal Biology,PMB 64, Minna, \\ Nigeria;israelolayemi2013@gmail.com
}

\begin{abstract}
Characterisation of germplasm collection is imperative for identification and selection of new resistance sources in any crop breeding programmes. Thus, evaluation of pearl millet germplasm for resistance to stem borer infestation was carried out in view of the challenges of poor yield and quality reduction of pearl millet, elicited by its feeding activities. Thirty-five (35) pearl millet accessions were collected from different states where the crop is majorly cultivated in Nigeria. The accessions were characterised for resistance to stem borer infestation on the field. Further confirmation for selected potentially resistant accessions under artificial screen house conditions was done using a randomised complete block design (RCBD) with ten replications each. The field estimated selection index showed that out of the 35 accessions screened, 15 accessions were potentially resistant; 13 resistants with range value of 0.00 to 0.40 and 2 moderately resistant. Further nursery screening confirmed 9 of the 15 accessions to be resistant under artificial infestation. NS-JIL-01 accession was most highly resistant with significant least leaf damage score of 0.25 . Significant and positive correlation $(r=0.32)$ was obtained between days to anthesis and number of larvae per plant at $p<0.01$. Negative correlation of percentage internodes damage with panicle diameter $(-0.26)$ and panicle weight $(-0.25 \mathrm{gn})$ at $\mathrm{p}<0.01$ as well as weight of 1000 seeds $(\mathrm{r}=-0.19, \mathrm{p}<0.05)$ were also significant. The identification of potentially resistant accessions on field and confirmation of some of the accessions under artificial screen house conditions indicated, gene for resistance to stem borer infestation in pearl millet could be obtained from the natural ecotype germplasm.
\end{abstract}

Keywords: germplasm; landraces; pearl millet; resistant; stem borer 


\section{Introduction}

Pearl millet [Pennisetum glaucum(L.) R. Br.] is an important global cereal crop mostly cultivated by the resource poor farmers in the semi-arid regions of sub-Saharan Africa and the Indian subcontinent for food and beverages (Haussmann et al., 2012; Abubakar et al., 2019). However, Gahukar and Reddy (2019) reported that the crop is infested by over 150 insect pests during its growth and development; with stem borer, shoot flies, leaf-sucking and panicle-attacking insects been considered economically important. Stem borers (Coniesta ignefusalis Hampson) has been reported to be a major pest of pearl millet in the Sahelian and sub-Saharan regions. According to Sastawa et al. (2002) and Barau et al. (2015), it is the most widespread and damaging insect pest of pearl millet in Nigeria. The larvae (caterpillars) infest all the plant growth stages; burrow tunnel into the stems causing them to fall over (lodging), 'dead hearts' and poor grain development (Obeng et al., 2015). In Northern Nigeria, the pest has been reported to infest $75.5 \%$ of the total pearl millet farms in the region. Early infestation by the insect results in total destruction of the growing points of crop, leading to premature plant death (Drame-Yaye et al., 2003). Late attack on older stage of the plants by tunneling larvae causes disruption of nutrient flow, stem lodging, flower abortion or chaffy grains or no grain formation, through the destruction of the apical tissues and vessels transporting the plant sap (Drame-Yaye et al., 2003; Singh et al., 2012). The use of chemicals in control of the pest is rarely justified due to difficulty in timing the application and cost. Efforts to control the pest through the combination of various cultural practices, such as early planting, practicing intercropping or the 'push-pull' system, and managing crop residues were not effective enough. Keeping in mind of these challenges, sourcing for biotic resistance traits among the available landraces have been considered as one of the viable and foremost options (Pattanashetti et al., 2016; Prakash et al., 2016).

Breeding programmes for insect resistance through host plant resistance (HPR) is an effective and friendly method to control insect pests with numerous benefits when present in commercial varieties. According to Crespo-Herrera et al. (2019); the advantages of HPR varies from reduction in insecticide usage and its subsequent production costs; decrease in negative effects of chemicals on the environment and nontargeted organisms. However, these advantages could only be explored through collection, screening of germplasm for insect resistant accession(s), and selection of elite genotypes in a breeding program. Amadou et al. (2013) reported that germplasm of pearl millet exhibits considerable variability for various agronomic traits such as stover characteristics, nutritional composition, and tolerance to biotic and abiotic stresses. Also, the local landraces with low yield potential, had been reported to be reasonably tolerant to wide range of biotic and abiotic stresses (Thakur et al., 2009). However, Angarawai et al. (2016) reported that in Nigeria, exploitation of the local landraces which serves as greatest reservoir of useful traits for improvement in this crop was done only to a limited extent in a very unsystematic manner. Also, Abubakar et al. (2019) reported that the global climate change ravaging most savanna region of Nigeria, has fast eroding effects on genetic variability of pearl millet as the natural habitats of wild cultivated species are being destroyed and modern cultivars is replacing the traditional cultivars. Therefore, research was carried out to source for stem borer resistant genotypes among the available landraces of pearl millets in the northern part of the country.

\section{Materials and Methods}

\section{Collection of germplasm}

A total of thirty-five (35) pearl millet accessions were collected from the major growing states (Adamawa, Gombe, Jigawa, Kano, Nasarawa, Niger, Kaduna, Sokoto, Taraba, and Zamfara) in the Northern Nigeria; twenty-five (25) landraces from farmers through direct contact and 10 genotypes from National Centre for Genetic Resources and Biotechnology (NACGRAB), Ibadan, Nigeria (Table 1). The genotypes were evaluated for stem borer infestation and some morphological characteristic on the field and further 
screened of selected potential resistant accessions were carried out at the screen house, Department of Plant Biology, Federal University of Technology, Minna.

Table 1. Germplasm information on collected 35 pearl millet landraces

\begin{tabular}{|c|c|c|c|c|c|}
\hline S/No. & $\begin{array}{c}\text { Accessions } \\
\text { Number }\end{array}$ & State & Place/Village & Source of Collection & Status \\
\hline 1 & NGB501 & Sokoto & Asarara & NACGRAB & Landraces \\
\hline 2 & NGB514 & Taraba & Sahwa & NACGRAB & Landrace \\
\hline 3 & NGB523 & Jigawa & Awekawa & NACGRAB & Landrace \\
\hline 4 & NGB528 & Gombe & Bajaga & NACGRAB & Landrace \\
\hline 5 & NGB571 & Jigawa & Awekawa & NACGRAB & Landrace \\
\hline 6 & NGB575 & Taraba & Gundunga & NACGRAB & Landrace \\
\hline 7 & NGB578 & Adamawa & Yafin & NACGRAB & Landrace \\
\hline 8 & NGB589 & Taraba & Garin Lange & NACGRAB & Landrace \\
\hline 9 & NGB594 & Kano & Zango Dan Audu & NACGRAB & Landrace \\
\hline 10 & NGB606 & Adamawa & Yafin & NACGRAB & Landrace \\
\hline 11 & NG-ZA-01 & Niger & Kutiriko & Farmer & Landrace \\
\hline 12 & NG-ZA-02 & Niger & Kutiriko & Farmer & Landrace \\
\hline 13 & NG-ZA-05 & Niger & Bida & Farmer & Landrace \\
\hline 14 & NG-ZA-08 & Niger & Enagi & Farmer & Landrace \\
\hline 15 & NG-ZB-01 & Niger & Shakwatu & Farmer & Landrace \\
\hline 16 & NG-ZB-03 & Niger & Pusama & Farmer & Landrace \\
\hline 17 & NG-ZC-01 & Niger & Kagara & Farmer & Landrace \\
\hline 18 & NG-ZC-02 & Niger & Kagara & Farmer & Landrace \\
\hline 19 & NG-ZC-03 & Niger & Jankasa & Farmer & Landrace \\
\hline 20 & KD-KG-01 & Kaduna & Kajon & Farmer & Landrace \\
\hline 21 & KD-CK-01 & Kaduna & Chikum & Farmer & Landrace \\
\hline 22 & KD-JB-01 & Kaduna & Jaba/Sabon Seriki & Farmer & Landrace \\
\hline 23 & KD-JM-01 & Kaduna & Kanafi/Agban & Farmer & Landrace \\
\hline 24 & NS-JIL-01 & Nasarawa & Jila & Farmer & Landrace \\
\hline 25 & NS-YEL-02 & Nasarawa & Yelwa Barau & Farmer & Landrace \\
\hline 26 & NS-YEL-06 & Nasarawa & Yelwa & Farmer & Landrace \\
\hline 27 & NS-YEL-07 & Nasarawa & Yelwa & Farmer & Landrace \\
\hline 28 & NS-GAN-04 & Nasarawa & Ganta & Farmer & Landrace \\
\hline 29 & NS-GAN-05 & Nasarawa & Ganta & Farmer & Landrace \\
\hline 30 & NS-GIN-03 & Nasarawa & Gidan Liman & Farmer & Landrace \\
\hline 31 & KN-MA-01 & Kano & Madigawa & Farmer & Landrace \\
\hline 32 & KN-GU-02 & Kano & Gurjiya & Farmer & Landrace \\
\hline 33 & JIG-DU-01 & Jigawa & Dutse & Farmer & Landrace \\
\hline 34 & JIG-BIR-01 & Jigawa & Birni Kudu & Farmer & Landrace \\
\hline 35 & ZF-ZM-01 & Zamfara & Zurmi & Farmer & Landrace \\
\hline
\end{tabular}

\section{Sowing and experimental design}

A total of 10 seeds per stand were sown for each accession on a ridge of $280 \mathrm{~cm}$ long with five stands per ridge, at a spacing of $50 \mathrm{~cm}$ for both inter and intra rows. The seedlings were thinned to 5 plants per stand at two weeks after germination, given a total of 25 plants per plot and 75 plants per accession using Randomised Complete Block Design (RCBD). Application of NPK fertilizer was done two weeks after thinning and no 
insecticides were applied throughout the experimental period. Weeding was done manually using hoe when necessary. Data were collected on ten (10) randomly selected and tagged plants per accession.

\section{Screening for sources of stem borer resistance in pearl millet germplasm}

Collection of data on stem borer infestation and damage rate was carried out using a modified destructive random sample technique of Khan et al. (2003) at the 50\% maturity of the plant. At early hour $(7: 00-9: 00 \mathrm{am})$ of the day, ten randomly selected plants from each accession were uprooted on the experimental field and examined for infestation. The plants were further grouped on the basis of the presence or absence of stem borer attacked symptoms. The leaves and leaf sheaths of the infested plant stems were removed and split open along the length (Figure 1). The number of non-infested and infested internodes, the numbers of entry holes, and the number of larvae were counted for each plant. Length of the damage tunnel was then measured for each infested internode and recorded. Morphological data were collected on twelve (12) quantitative traits base on standard descriptors for pearl millet (IBPGR and ICRISAT, 1993). Selection of potential resistance genotypes was based on estimated selection index from stem borer damage related parameters data
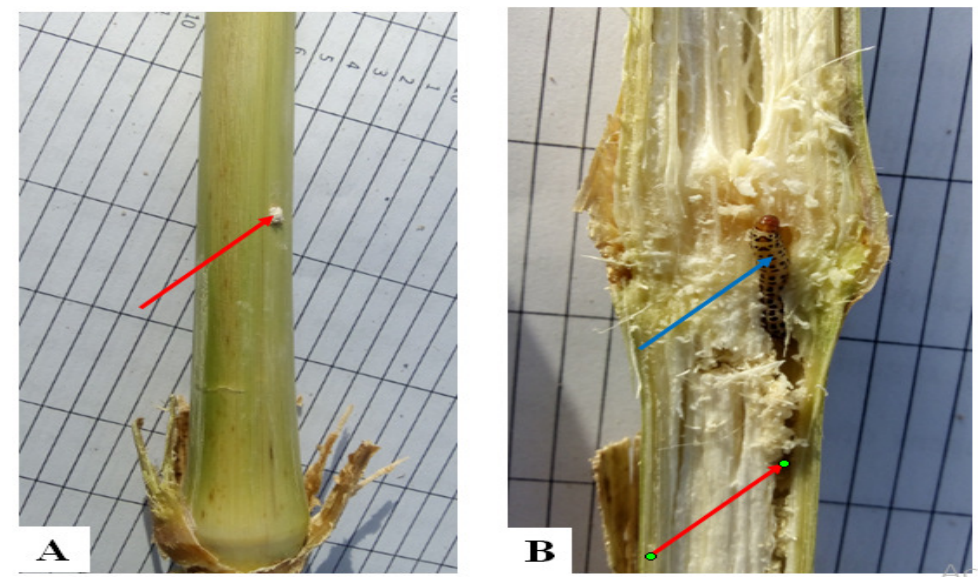

Figure 1. Pearl millet stem infested and damage by stem borer (Coniesta ignefusalis) $A=$ Entry hole of stem borer on stem of a susceptible pearl millet $\mathrm{B}=$ Blue arrow - Stem borer organism, Red arrow - Damage (Tunnel length) stem

\section{Artificial infestation with stem borer}

The Screen house evaluation was done using modified method of Qiu et al. (2010, 2012). The selected potentially identified field resistant accessions and two most susceptible accessions NGB606 and NG-ZC-03 (to serve as check) were planted in nursery pots at the screen house temperature $\left(27 \pm 3^{\circ} \mathrm{C}\right)$. Twelve seedlings of each selected accession were randomly picked and sown in experimental box of $(15 \times 9 \times 5) \mathrm{cm}^{3}$ dimensions. The seedlings were sown in two rows of $9 \mathrm{~cm}$ long, with intra and inter row spacing of 3.00 and $4.00 \mathrm{~cm}$ respectively. At the second-leaf stage ( 14 days old), the seedlings were infested with 2 nd-3rd instars larvae at 5 insects/box. To optimise larval establishment, infestation of the seedling was done after subjecting the larvae to fasting for 24 hours. The boxes were covered with a fine gauge nylon-net cage (of approximately $16 \times 10 \times 30$ $\mathrm{cm}$ ) after infestation and fastened with rubber band. The experimental set-up was replicated tree times under natural day light and darkness at screen house temperature $\left(27 \pm 3^{\circ} \mathrm{C}\right)$. Each seedling was examined for leaf damage, signs of holes on the stem and the production of dead heart characteristic when all the check seedlings had fully been infested or died at 17 days. The seedlings were then given scores (Table 2) based on the damage rate on a scale of 0 - 9 according to SES/IRRI (2002). The resistance score of each accession was then inferred from the mean of all the seedlings rating scores and the number of infested seedlings were expressed in percentage. 
Table 2. Leaf damage rating of pearl millet for resistance to Coniesta ignefusalis

\begin{tabular}{|c|c|c|}
\hline Score & Percentage infested plants & Rating (reaction) \\
\hline 0 & No visible leaf feeding damage & Highly resistance \\
\hline 1 & Less than $1 \%$ injury with shot-holes on a few leaves & Resistance \\
\hline 3 & $1-5 \%$ injury with lesions on a few leaves & Moderately resistance \\
\hline 5 & $6-10 \%$ injury with lesions on a several leaves & Moderately susceptible \\
\hline 7 & $11-25 \%$ injury with lesions on a several leaves & Susceptible \\
\hline 9 & Above $25 \%$ injury with plant dying due to foliar damage & Highly susceptible \\
\hline
\end{tabular}

\section{Analysis of stem borer infestation indices}

The percentage of stems damaged by $C$. ignefusalis was expressed as a proportion of the total number of infested internodes per plant. Similarly, dead-heart incidence was computed as the percentage expression of the number of plants showing dead-hearts to the total number of plants sampled. The length of stem burrow (tunnel) was expressed as an average of the tunnel stem per plant. The total number of $C$. ignefusalis larvae recovered per sample was taken and expressed as an estimate of the larval population per plot. The computed stem borer damage related parameters (percentage stem damage, dead hearts incidence, stem tunneling and number of entry holes and larva per plant) were used to estimate the selection index and delineate the genotypes reaction to $C$. ignefusalis infestation. Selection index was determined by dividing the sum of the ratio between the values for individual genotype and their overall mean for each parameter (percentage stem damage, dead hearts incidence, stem tunneling and exit holes) by the number of parameters used (Tefera et al., 2011).

\section{Data analysis}

Data obtained on the field insect damage were expressed in simple percentage using Microsoft excel. Data on artificial screening of selected potential resistant accessions were polled for analysis of variance (ANOVA) to determine the level of significance within the means and Ducans' multiple range test was used to separate the means where there were differences using Statistical Package for Social Sciences (SPSS) software, version 18. Pearson correlation of disease and insect indices with morphological parameters was also done using SPSS.

\section{Results}

\section{Damage effects of Coniesta ignefusalis on pearl millet landraces}

The feeding effects of $C$. ignefusalis on the collected accessions of pearl millet varied in terms of stem damage, dead heart formation, stem tunneling, number of entry holes and number of larvae (Table 3). NGB523 had the highest stem damage with the value of $47.88 \%$ followed by NGB514 (47.30\%). Except for damage free accessions, the highest dead heart of $86.67 \%$ was recorded in NG-ZC-03 and least was obtained in NGB606 with the value of $23.33 \%$. The highest number of larvae per plant (3.67) was obtained in JIG-BIR-01, followed by 2.67 in accessions NG-ZA-08, NG-ZC-03 and KD-JB-01. Based on estimated selection index, thirteen of the accessions were resistant with range selection index of 0.00 to 0.13 . KN-GU-02 and NS-GAN-04 were moderately resistant (tolerant) with selection index of 0.97 and 0.98 respectively. The highest susceptible accession was NG-ZC-03 (2.78) followed by NGB523 with selection index of 2.60 (Table 3). 
Table 3. Effects of Coniesta ignefusalis on 35 pearl millet accessions under field condition

\begin{tabular}{|c|c|c|c|c|c|c|c|}
\hline Accessions & $\begin{array}{c}\text { \% Damage } \\
\text { Stem }\end{array}$ & $\begin{array}{c}\text { \% Dead } \\
\text { heart }\end{array}$ & $\begin{array}{c}\text { Stem } \\
\text { tunnelling }\end{array}$ & $\begin{array}{c}\text { Number of } \\
\text { entry hole }\end{array}$ & $\begin{array}{c}\text { Number of } \\
\text { larvae }\end{array}$ & $\begin{array}{c}\text { Selection } \\
\text { index } \\
\end{array}$ & Status \\
\hline NGB501 & 12.13 & 26.67 & 6.4 & 3.67 & 1.33 & 1.23 & MS \\
\hline NGB514 & 47.3 & 60 & 14.67 & 2 & 1.33 & 2.3 & HS \\
\hline NGB523 & 47.88 & 70 & 4.47 & 12.67 & 0.67 & 2.6 & HS \\
\hline NGB528 & - & - & - & - & - & - & HS \\
\hline NGB571 & 2.56 & 0 & 0 & 0 & 0 & 0.04 & $\mathrm{R}$ \\
\hline NGB575 & - & - & - & - & - & - & HS \\
\hline NGB578 & - & - & - & - & - & - & HS \\
\hline NGB589 & 0 & 0 & 0 & 0 & 0 & 0 & $\mathrm{R}$ \\
\hline NGB594 & 0 & 0 & 0 & 0 & 0 & 0 & $\mathrm{R}$ \\
\hline NGB606 & 29.72 & 23.33 & 15.67 & 3.33 & 3.33 & 2.27 & $\mathrm{HS}$ \\
\hline NG-ZA-01 & 0 & 0 & 0 & 0 & 0 & 0 & $\mathrm{R}$ \\
\hline NG-ZA-02 & 0 & 0 & 0 & 0 & 0 & 0 & $\mathrm{R}$ \\
\hline NG-ZA-05 & - & - & - & - & - & - & $\mathrm{HS}$ \\
\hline NG-ZA-08 & 11.27 & 40 & 3.77 & 4.67 & 2.67 & 1.56 & MS \\
\hline NG-ZB-01 & - & - & - & - & - & - & HS \\
\hline NG-ZB-03 & 0 & 0 & 0 & 0 & 0 & 0 & $\mathrm{R}$ \\
\hline NG-ZC-01 & 2.78 & 0 & 0.53 & 0 & 0.33 & 0.13 & $\mathrm{R}$ \\
\hline NG-ZC-02 & 0 & 0 & 0 & 0 & 0 & 0 & $\mathrm{R}$ \\
\hline NG-ZC-03 & 36.3 & 86.67 & 13.87 & 4.67 & 2.67 & 2.78 & HS \\
\hline KD-KG-01 & 18.16 & 40 & 8.23 & 6.33 & 1.33 & 1.71 & HS \\
\hline KD-CK-01 & 35.19 & 46.67 & 7.5 & 8.67 & 1.67 & 2.24 & HS \\
\hline KD-JB-01 & 20.24 & 36.67 & 9.73 & 12 & 2.67 & 2.47 & HS \\
\hline KD-JM-01 & 0 & 0 & 0 & 0 & 0 & 0 & $\mathrm{R}$ \\
\hline NS-JIL-0 1 & 0 & 0 & 0 & 0 & 0 & 0 & $\mathrm{R}$ \\
\hline NS-YEL-02 & 24.24 & 26.67 & 11.77 & 6 & 0.67 & 1.7 & $S$ \\
\hline NS-YEL-06 & 0 & 0 & 0 & 0 & 0 & 0 & $\mathrm{R}$ \\
\hline NS-YEL-07 & 36.67 & 46.67 & 10.13 & 10.33 & 2 & 2.57 & $\mathrm{HS}$ \\
\hline NS-GAN-04 & 7.03 & 36.67 & 6.03 & 1.33 & 1 & 0.98 & MR \\
\hline NS-GAN-05 & 0 & 0 & 0 & 0 & 0 & 0 & $\mathrm{R}$ \\
\hline NS-GIN-03 & 16.21 & 70 & 14.6 & 5.67 & 3.33 & 2.57 & HS \\
\hline KN-MA-01 & 21.11 & 70 & 9.5 & 2.67 & 2.33 & 2 & HS \\
\hline KN-GU-02 & 15.48 & 30 & 2.9 & 2 & 1 & 0.97 & MR \\
\hline JIG-DU-01 & 0 & 0 & 0 & 0 & 0 & 0 & $\mathrm{R}$ \\
\hline JIG-BIR-01 & 36.51 & 53.33 & 10.6 & 4 & 3.67 & 2.52 & HS \\
\hline Mean & 12.77 & 23.9 & 4.55 & 2.73 & 0.99 & & \\
\hline Std. Dev. & 17.14 & 29.47 & 6.43 & 4.21 & 1.39 & & \\
\hline
\end{tabular}

Rating scale with 0.0 - 0.6 is Resistant (R); 0.7 - 0.9 Moderately Resistant (MR); 1.0-1.6 Moderately Susceptible; 1.7

- 1.9 Susceptible (S); Above 1.9 highly susceptible (HS).

$\mathrm{NB}$ - indicate no reading were taking due death of the plant before dough stage.

\section{Reaction of selected pearl millet to stem borer under artificial infestation}

Artificial screening of selected potential resistant accessions showed that there was great variation in response of the accessions (Table 4). The susceptible checks (NGB606 and NG-ZC-03) have high percentage infestation (91.67\% and 83.33\%, respectively) with significant mean damage scores of 6.75 and 6.17, respectively. These mean values were not significantly different from the mean value (6.33) of NGB589 with percentage infestation rate of $83.33 \%$. Of the 15 selected resistant accessions from the field, 9 accessions equivalent to $60 \%$ proved to be resistant under artificial infestation; with KD-JM-01 being highly resistant (HR), 2 accessions (NG-ZB-03 and KN-GU-02) moderately resistant (MR) and 6 accessions being resistant 
(R). Statistical analysis of the mean damage score showed that 0.25 of KD-JM-01 was significantly differently from the value of all other accessions (Table 4). However, all other initially selected resistant accessions from the field screening are moderately susceptible to $C$. ignefusalis under artificial infestation.

Table 4. Reaction of selected pearl millet accessions to artificial stem borer infestation

\begin{tabular}{|c|c|c|c|}
\hline Accession & Percentage infested seedling & Mean damage score & Host reaction \\
\hline *NGB606 & 91.67 & $6.75 \mathrm{~d}$ & MS \\
\hline NGB571 & 91.67 & $5.17 \mathrm{c}$ & MS \\
\hline NGB589 & 83.33 & $6.33 \mathrm{~d}$ & MS \\
\hline NGB594 & 25 & $5.25 c$ & MS \\
\hline NG-ZA-01 & 50 & $1.50 \mathrm{ab}$ & $\mathrm{R}$ \\
\hline NG-ZA-02 & 75 & $5.58 \mathrm{~cd}$ & MS \\
\hline NG-ZB-03 & 66.67 & $3.00 \mathrm{~b}$ & MR \\
\hline NG-ZC-01 & 33.33 & $1.00 \mathrm{ab}$ & $\mathrm{R}$ \\
\hline NG-ZC-02 & 58.33 & $2.25 \mathrm{ab}$ & $\mathrm{R}$ \\
\hline${ }^{*} \mathrm{NG}-\mathrm{ZC}-03$ & 83.33 & $6.17 \mathrm{~d}$ & MS \\
\hline KD-JM-01 & 25 & $0.25 \mathrm{a}$ & HR \\
\hline NS-JIL-01 & 50 & $1.00 \mathrm{ab}$ & $\mathrm{R}$ \\
\hline NS-YEL-06 & 66.67 & $5.00 \mathrm{c}$ & MS \\
\hline NS-GAN-04 & 50 & $2.00 \mathrm{ab}$ & $\mathrm{R}$ \\
\hline NS-GAN-05 & 75 & $5.08 \mathrm{c}$ & MS \\
\hline KN-GU-02 & 66.67 & $3.33 \mathrm{~b}$ & MR \\
\hline JIG-DU-01 & 41.67 & $1.08 \mathrm{ab}$ & $\mathrm{R}$ \\
\hline Mean & 60.78 & 3.57 & \\
\hline $\mathrm{CV}$ & 2.81 & 1.02 & \\
\hline
\end{tabular}

Accession with * are susceptible checks.

Values with the same alphabet along the column are not significantly different.

Mean damage Score value of < 1.0 Highly Resistant (HR), 1.00-2.99 Resistant (R), 3.00-4.99 Moderately Resistant

(MR), 5.00-6.99 Moderately Susceptible (MS), 7.00-8.99 Susceptible (S) and 9.0 Highly Susceptible (HS).

\section{Correlation of disease and insect indices with morphological parameters}

Insect susceptibility indices were all positively correlated with one another at $\mathrm{p}<0.01$. Significant and positive correlation $(\mathrm{r}=0.32)$ was obtained between days to anthesis and number of larvae per plant at $\mathrm{p}<$ 0.01 . Percentage internodes damage (PID) was negatively correlated number of leaves per plant with value of $r$ $=-0.27$ at $\mathrm{p}<0.01$. Also, significant, and negative correlation of PID with panicle diameter $(-0.26)$ and weight $(-0.25)$ at $\mathrm{p}<0.01$ as well as weight of 1000 seeds $(\mathrm{r}=-0.19, \mathrm{p}<0.05)$ were recorded. Except for panicle length (0.07), dead heart was negatively correlated with all the panicle parameters, however, these values were not significant. Number of larvae was positively and significantly correlated with number of days to anthesis $(\mathrm{p}<$ $0.01, \mathrm{r}=0.32$ ) Table 5 . 
Table 5. Pearson correlation of disease and insect indices with morphological parameters in pearl millet germplasm

\begin{tabular}{|c|c|c|c|c|c|c|c|c|c|c|c|c|c|}
\hline & PID & $\% \mathrm{DH}$ & $\mathrm{NEH}$ & NLP & PLH & NLPP & NIPP & STD & DTA & PAL & PAD & PAW & OSW \\
\hline PID & 1 & & & & & & & & & & & & \\
\hline$\% \mathrm{DH}$ & $0.70^{* *}$ & 1 & & & & & & & & & & & \\
\hline $\mathrm{NEH}$ & $0.64^{* *}$ & $0.46^{* *}$ & 1 & & & & & & & & & & \\
\hline NLP & $0.55^{* *}$ & $0.57^{* *}$ & $0.53^{*}$ & 1 & & & & & & & & & \\
\hline PLH & -0.10 & 0.1 & 0.00 & 0.14 & 1 & & & & & & & & \\
\hline NLPP & $-0.26^{* *}$ & 0.09 & -0.07 & 0.14 & $0.58^{* *}$ & 1 & & & & & & & \\
\hline NIPP & $-0.27^{* *}$ & 0.09 & -0.03 & 0.16 & $0.59^{* *}$ & $0.93^{* *}$ & 1 & & & & & & \\
\hline STD & -0.07 & 0.05 & -0.09 & 0.11 & $0.19^{* *}$ & $0.16^{*}$ & $0.15^{*}$ & 1 & & & & & \\
\hline DTA & 0.08 & $0.20^{*}$ & 0.08 & $0.32^{* *}$ & 0.02 & -0.07 & 0.01 & -0.06 & 1 & & & & \\
\hline PAL & 0.08 & 0.07 & 0.07 & 0.1 & $0.16^{* *}$ & $-0.14^{*}$ & -0.11 & -0.10 & 0.16 & 1 & & & \\
\hline PAD & $-0.26^{* *}$ & -0.04 & -0.09 & -0.1 & $0.32^{* *}$ & $0.43^{* *}$ & $0.38^{* *}$ & $0.22^{* *}$ & $-0.25^{* *}$ & -0.11 & 1 & & \\
\hline PAW & $-0.25^{* *}$ & -0.07 & -0.13 & -0.18 & $0.41^{* *}$ & $0.27^{* *}$ & $0.23^{* *}$ & $0.14^{*}$ & -0.18 & $0.17^{* *}$ & $0.45^{* *}$ & 1 & \\
\hline OSW & -0.19 & -0.03 & -0.09 & 0.04 & $0.38^{* *}$ & $0.35^{* *}$ & $0.29^{* *}$ & -0.04 & -0.03 & 0.12 & $0.40^{* *}$ & $0.51^{* *}$ & 1 \\
\hline
\end{tabular}

${ }^{*}=$ Significant at $\mathrm{P}<0.01,{ }^{*}=$ Significant at $\mathrm{P}<0.05$

PID: percentage internode damage, DH: dead heart, NEH: number of entry holes, NLP: number of larvae per plant, PLH: plant height, NLPP: number of leaf per plant, NIPP: number of internode per plant, STD: stem diameter, DTA: days to anthesis, PAL: panicle length, PAD: panicle diameter, PAW: panicle weight, OSW: one thousand seed weight.

\section{Discussion}

Pest resistance traits are polygenic characters inherited in a quantitative manner under the influence of some environmental factors (Tefera et al., 2011). The pre-mature death of some accessions could be attributed to the inability of these susceptible accessions to resist or tolerate the infestation of the stem borer and their subsequent predisposition to secondary attack of diseases. In line with assertion Drame-Yaye et al. (2003) reported that stem borer early infestation on plant by the first generation of the pest results in premature death due to their feeding damage on the plant stalks and destruction of the growing points after bored in. Also, it has earlier been reported that stem borers inject toxic secretions and transmit diseases to plant while feeding on its sap (Akhtar et al., 2012). Similarly, susceptibility of plant to insect infestation has been attributed to its fitness and adaptation (Murenga et al., 2016).

Selection indices are effective techniques for identification of stem borer resistance genotype(s) since it combines information of different agronomic traits of interest with the genetic properties of a population. The identification of fifteen (15) potential resistant pearl millet accessions to stem borer infestation on field and the confirmation of nine (9) of the accessions under artificial screen house conditions indicate that resistant genotypes could be sourced from the natural germplasm for the crop improvement. In conformity with result obtained in this present research, Rahman et al. (2004), who assessed infestation and yield loss by stem borers on variety of rice, reported that local varieties were resistant. Also, Murenga et al. (2016) reported that identified inbred lines resistant to stem borer may be used as parents in hybrid breeding programmes that emphasize stem borer resistance or as sources of resistance in breeding programs. Plant breeders and entomologists have investigated the inheritance of resistance to identify diverse genes for resistance. The disparity in resistance of the 13 selected potentially resistant and the 2 moderately resistant genotypes could be attributed to variation in their genetic composition and resistant gene(s).

The variation in the resistance of some selected genotypes under artificial infestation to the field could be attributed to the exclusion of external factors such as soil fertility, weeds, drought and environmental factors that influenced their susceptibility to stem borer attack. The higher percentage of infestation obtained in all the accessions examined in screen house could be attributed to the age and soft nature of their tissue for easy feeding tunneling. In line with this assertion, morphological factors such as leaf fibre, surface wax, silica and high hemicelluloses have been reported to influence the nature and texture of any plant and increases with the plant age (Firdous and Gilani, 2001). These factors have been identified as resistance mechanisms against stem 
borers (Bergvinson et al., 1995). The present results also support the report of Drame-yaye et al. (2003) that young plants artificially infested were more sensitive to dead-heart formation than older ones and early infestations result in maximum damage. Also, in conformity with this report, high number of insect pest progenies and infestation among genotypes of pearl millet (Pennisetum glaucum L.) has been associated with higher proportion of soft endosperm due to easy tunneling and adequate sap for feeding (Siwale et al., 2009).

The negative correlation of the insect indices (percentage damage internodes, dead-heart formation, number of holes and number of larvae) to the panicle parameters indicate that susceptibility of the crop to insect infestation lead to reduction in the yield of the plant. This reduction could be ascribed to the level of destruction in xylem and phloem tissues of the plant due to dead-heart formation and hindering of translocation of water and minerals as well as hampering of translocation of food materials; hence, failure in production of panicles. This result is in line with the statement of Muturi et al. (2012) who attributed the significant loss of grain yield due to dead-heart formation to the destruction in of apical shoot of the main stem leading to the production of unproductive tillers. The significant positive correlation between days to anthesis and number of larvae indicate that, larva emergence and population are influenced by the reproductive stage of the plant. The emergence of larva at the period could be attributed to availability of food for their survival. In agreement with this result, Obeng et al. (2015) reported that insect numbers peaked during the reproductive stage of the crop at flowering through seed filling stages of the crop. This contrasts with the result of Sarao and Mahal (2012), who obtained a strong correlation between plant height and percentage dead-hearts formation, there was no correlation between dead-heart and plant height. However, dead-heart is significantly and positively correlated to number of larvae, an indication that dead-heart formation is a function and expression of number of larvae and entry holes created by the organism. In contrast to this observation, Khan et al. (2003) who evaluated some rice varieties against stem borer reported that dead-heart formation was not true reflection of stem borer infestation level. They attributed this variation to the predominant nature of the yellow stem borer species and its relatively low population in the beginning of the crop growing season, which could have limited the formation of dead heart by the insect. In conformity with earlier report of Mohyuddin and Attique (1978); Chouraddi and Mallapur (2017), it was observed that major loss in grain weight was due to dead hearts and stunting of the growth rather than tunnelling. The negative correlation of dead heart formation to panicle diameter, panicle weight and 1000 seed weight obtained, inferred that stem borer susceptibility could lead to general weakness of the stem and conductive tissues, leading to loss of essential nutrients needed for plant support and yield formation.

\section{Conclusions}

It is established that considerable high variability exists among landraces of pearl millet in Nigeria for different traits such as resistance to stem borer infestations. Variation in the resistance and susceptibility of the accessions both on the field and nursery screening, demonstrated the inherent resistant potentials of some accessions as sources of resistance to stem borer infestation in pearl millet and could be obtained from the natural eco-type germplasm. Based on the resistance capability of KD-JM-01, it has been identified and selected for, as elite parent accessions that could be used for the crop improvement in stem borer resistance breeding programs.

\section{Authors' Contributions}

AA; The researcher involved in all aspects of the research and writing; FOA; Major supervision, review, and editing; OIK and AMO; Supervision, review, and editing; DOAY; Research coordination and validation; DMC; Research assistant and Data collection. All authors read and approved the final manuscript. 


\section{Acknowledgements}

This research received no specific grant from any funding agency in the public, commercial, or not-forprofit sectors.

\section{Conflict of Interests}

The authors declare that there are no conflicts of interest related to this article.

\section{References}

Abubakar A, Falusi OA, Adebola MO, Olayemi IK, Daudu OAY (2019). Genetic diversity studies for morphological traits in pearl millet (Pennisetum glaucum L.) landraces of Northern Nigeria. GSC Biological and Pharmaceutical Sciences 7(2):60-70. https://doi.org/10.30574/gscbps.2019.7.2.0070

Akhtar N, Ahmad Y, Shakeel M, Gillani WA, Khan J, Yasmin T, Begum I (2012). Resistance in pearl millet germplasm to greenbug, Schizaphis graminum (Rondani). Pakistan Journal of Agricultural Research 25(3):228-232.

Amadou I, Gounga ME, Le GW (2013). Millets, nutritional composition, some health benefits and processing. Emirates Journal of Food and Agriculture 25:501-508. https://doi.org/10.9755/ejfa.v25i7.12045

Angarawai II, Aladele S, Dawud MA, Turaki ZGS, Yakub Y (2016). Genetic diversity among Nigeria 'Maiwa Type' of Pearl Millet germplasm. Global Journal of Science Frontier Research 16(3):14 -20.

Barau BW, Wama BE, Maikeri TC (2015). Incidence of the millet stem borer Coniesta ignefusalis (Hampson) in farmers' fields of Lamma and Dingding villages of zing local government area. International Journal of Bioscience 10(1):107-111.

Bergvinson DJ, Vasal SK, Singh NN, Panwar VPS, Sekhar JC (2004). Advances in conventional breeding for insect resistance in tropical maize. In: Srinivasan G, Zaidi PH, Prasanna BM, Gonzalez F, Lesnick K (Eds). New Technologies for the New Millennium. Proceedings of the 8th Asian Regional Maize Workshop, 5-8 August 2002. Bangkok, Thailand: CIMMYT pp 325-338.

Chouraddi M, Mallapur CP (2017). Assessment of crop loss and economic injury level of maize stem borer, Chilo partellus (Swinhoe). Journal of Entomology and Zoology Studies 5(4):1530-1535. https://www.entomoljournal.com/archives/2017/vol5issue4/PartT/5-4-155-135.pdf

Crespo-Herrera LA, Singh RP, Sabraoui A, El-Bouhssini A (2019). Resistance to insect pests in wheat-rye and Aegilops speltoides Tausch translocation and substitution lines. Euphytica 215:123. https://doi.org/10.1007/s10681019-2449-7

Drame-Yaye A, Youm O, Ayertey JN (2003). Assessment of grain yield losses in pearl millet due to the millet stemborer, Coniesta ignefusalis (Hampson). Insect Science and its Application 23(3):259-265. https://doi.org/10.1017/S1742758400023651

Firdous R, Gilani AH (2001). Changes in chemical composition of sorghum as influenced by growth stage and cultivar. Asian-Australasian Journal of Animal Sciences 14(7):935-940.

Gahukar RT, Reddy GVP (2019). Management of economically important insect pests of Millet. Journal of Integrated Pest Management 10(1):1-10. https://doi.org/10.1093/jipm/pmz026

Haussmann BIG, Fred RH, Weltzien-Rattunde E, Traoré PSC, vom-Brocke K, Parzies HK (2012). Breeding strategies for adaptation of pearl millet and sorghum to climate variability and change in West Africa. Journal of Agronomy and Crop Science 198:327-339. https://doi.org/10.1111/j.1439-037X.2012.00526.X

IBPGR, ICRISAT (1993). Descriptors for pearl millet [Pennisetum glaucum (L.) R. Br.]. International Board for Plant Genetic Resources, Rome, Italy, and International Crops Research Institute for the Semi-Arid Tropics, Patancheru, Andhra Pradesh, India, ICRISAT, pp 13-35.

Khan M, Saljoqi A, Latif A, Abdullah K (2003). Evaluated some rice varieties against stem borer (Tryporyza incertulas). Asian Journal of Plant Sciences 2(6):498-500. https://doi.org/10.3923/ajps.2003.498.500

Mohyuddin AI, Attique MR (1978). An assessment of loss caused by Chilo partellus (Swinh.) to maize in Pakistan. PANS 24:111-113. https://doi.org/10.1080/09670877809411600 
Murenga M, John DJ, Mugo S, Tongoona P, Lilian G (2016). Evaluation of tropical maize inbred lines for resistance to two stem borer species, Busseola fusca and Chilo partellus. Journal of Plant Breeding and Crop Science 8(2):2333. https://doi.org/10.5897/JPBCS2015.0526

Muturi PW, Rubaihayo P, Mgonja M, Kyamanywa S, Sharma HC, Hash CT (2012). Novel source of sorghum tolerance to the African stem borer, Busseola fusca. African Journal of Plant Science 6(11):295-302. https://doi.org/10.5897/AJPS12.051

Obeng E, Cebert E, Ward R, Nyochembeng LM, Mays DA, Singh HP, Singh BP (2015). Insect incidence and damage on pearl millet (Pennisetum glaucum) under various nitrogen regimes in Alabama. Florida Entomologist 98(1):7479. $h$ ttp://dx.doi.org/10.1653/024.098.0113

Pattanashetti SK, Upadhyaya HD, Dwivedi SL, Vetriventhan M, Redd KN (2016). Pearl Millet. In: Singh M, Upadhyaya HD (Eds). Genetic and genomic resources of grain legume improvement. Oxford Academic Press, Heidelberg, London New York, pp 253-289

Prakash G, Srinivasa N, Sankar SM, Singh SP, Satyavathi CT (2016). Standardization of pearl millet blast (Magnaporthe grisea) phenotyping under artificial conditions. Annals of Agricultural Research 37(2):200-205.

Qiu YF, Cheng L, Zhou P, Liu F, Li R (2012). Identification of antixenosis and antibiosis in two newly explored brown planthopper-resistance rice lines. Advance Journal of Food Science and Technology 4(5):299-303. https://maxwellsci.com/print/ajfst/v4-299-303.pdf

Qiu YF, Guo JP, Jing SL, Zhu LL, He GC (2010). High-resolution mapping of the brown planthopper resistance gene Bph6 in rice and characterizing its resistance in the 9311 and Nipponbare near isogenic backgrounds. Theoretical and Applied Genetics 121:1601-1611. https://doi.org/10.1007/s00122-010-1413-7

Rahman MDT, Khalequzzaman M, Khan MAR (2004). Assessment of infestation and yield loss by stem borers on variety of rice. Journal of Asia-Pacific Entomology 7(1):89-95. www.entomology.or:kr

Sarao PS, Mahal MS (2012). Evaluation of rice germplasm for resistance to a leaf folder stemborer and planthopper under field and glasshouse conditions in India. International Journal of Tropical Insect Science 2(3):126-135. https://doi.org/10.1017/S1742758412000203

Sastawa BM, Lale NES, Ajayi O (2002). Evaluating host plant resistance and sowing date modification for the management of the stem borer, Coniesta ignefusalis Hampson and the head miner Heliocheilus albipunctella de Joannis infesting pearl millet in the Nigerian Sudan Savanna. Journal of Plant Diseases and Protection 109(5):530-542. https://www.jstor.org/stable/43215474.seq=1

SES/IRRI (2002). Standard Evaluation System. International Rice Research Institute, Manila, Philippines, pp 11-30.

Singh BU, Sharma HC, Rao KV (2012). Mechanisms and genetic diversity for host plant resistance to spotted stem borer, Chilo partellus in sorghum, Sorghum bicolor. Journal of Applied Entomology 136:386400. https://doi.org/10.1111/j.1439-0418.2011.01647.x

Siwale J, Mbata K, Mcrobert, J, Lungu D (2009). Comparative resistance of improved maize genotypes and Landraces to maize weevil. African Crop Science Journal 17:1-16. https://doi.org/10.4314/acsj.v17i1.54206

Tefera T, Mugo S, Tende R, Likhayo P (2011). Methods of screening maize for resistance to stem borers and post-harvest insect pests. Nairobi, Kenya, International Maize and Wheat Improvement Center (CIMMYT), pp 1-19. https://repository.cimmyt.org/handle/10883/817

Thakur RP, Rao VP, Sharma R (2009). Temporal virulence change and identification of resistance in pearl millet germplasm to diverse pathotypes of Sclerospora graminicola. Journal of Plant Pathology 91(3):629-636. https://www.jstor.org/stable/41998680
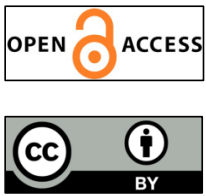

The journal offers free, immediate, and unrestricted access to peer-reviewed research and scholarly work. Users are allowed to read, download, copy, distribute, print, search, or link to the full texts of the articles, or use them for any other lawful purpose, without asking prior permission from the publisher or the author.

License - Articles published in Notulae Scientia Biologicae are Open-Access, distributed under the terms and conditions of the Creative Commons Attribution (CC BY 4.0) License.

(c) Articles by the authors; SHST, Cluj-Napoca, Romania. The journal allows the author(s) to hold the copyright/to retain publishing rights without restriction. 